\title{
Incivility In The Accounting Classroom
}

\author{
Laurie Swinney, University of Nebraska at Kearney, USA \\ Bruce Elder, University of Nebraska at Kearney, USA \\ Lloyd "Pat" Seaton, University of Northern Colorado, USA
}

\begin{abstract}
Classroom incivility is any action that interferes with a harmonious and cooperative learning atmosphere in the classroom (Feldman, 2001). We compared the perceptions of accounting faculty to the perceptions of cross-disciplinary faculty relating to both the definition of student actions as incivility and the occurrence of incivility. We also compared faculty and business administrator perceptions to investigate the level of administrator awareness of accounting classroom incivility. Our results indicate that accounting faculty are more likely to define potentially disruptive student behaviors as incivility and reported higher levels of classroom incivility than cross-disciplinary faculty. We find general agreement between accounting faculty and business administrators relating to both the definition and occurrence of incivility.
\end{abstract}

Keywords: Classroom incivility, college teaching, disruptive student behaviors

\section{INTRODUCTION}

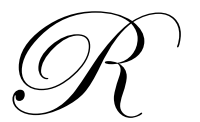

ecent episodes of incivility in the political, entertainment, and sports arenas have brought the issue of incivility to the forefront of public attention (della Cava, 2009). The problem of incivility, however, is not new. Over a decade ago, a U.S. News and World Report poll (1996) found that $89 \%$ of Americans believed that incivility was a major social problem. Royce (1998) stated that cynicism and meanness run deep and wide in American society and is far more common than concern for the common good. In The Triumph of Meanness: American's War Against Its Better Self, Mills (1997) provided examples of ways in which Americans publicly engaged in cruelty toward those viewed as vulnerable. A 2000 Gallup poll and a 1999 ABC NEWS poll reported that approximately three-fourths of Americans believed that rude and selfish behavior was worse than in the past (Libaw, 2003). Although a 2003 Public Agenda study reported that Americans were more thoughtful and caring after the September 11 attacks, most of the respondents $(66 \%)$ believed that the positive change was only short-term and about one-fourth believed that the good feeling had already passed (Libaw, 2003).

Although incivility is readily recognized, civility is difficult to define. Many simply connote civility with courtesy and good manners. Others associate civility with civic duty and community service. Carter (1998), however, argues that civility is the sum of the many sacrifices we are called to make for the sake of living together. He states that civility is a virtue that gives us the tools for interacting with others. Carter notes that the word civility is based on the Indo-European root meaning "member of the household." Thus, civility is all about community and the common good while incivility is all about self and a failure to respect fellow members of the community.

Just as most Americans believe that incivility is a major social problem, Levine \& Cureton (1998) found that most deans (57\%) believe that civility has also declined on the college campus. Baldwin (2002) sites that frequent reports in the Chronicle of Higher Education and the popular press demonstrate that "incivility within the academic community is too damaging to ignore." In his Fall Address to the University, Dr. Albert Yates (1999, p. 3), President of Colorado State University said:

As proud as we are of our students, though, we must also acknowledge that nationwide and even on our own campus, we are seeing a growing incivility and boorishness among too many people--even at times among faculty and staff. We see too many students who view rowdiness and binge drinking as a normal way to have fun on a Saturday night. We see men and women who don't seem to know how to treat each other with respect, both 
physically and verbally. These are not problems solely of Colorado State University but for every institution of higher education in America. (Emphasis added)

According to Boyer (1990, p. 7) the university should be "an open community, a place where freedom of expression is uncompromisingly protected and where civility is powerfully affirmed." Connelly (2009), however, documents reports of incivility in the university and then focuses on the need for civility education to enable firsttime college students to adapt to the academic community. Royce $(1998$, p. 2$)$ also links the ideas of community and civility on campus, stating "Civility and community are contingent upon each other-as one goes so goes the other." In a community, individuals have shared values and work together for the common good. It follows that in an ideal classroom community, faculty and students would also have shared values and work together for the common good. Davis (2004) discusses how faculty and students may actually have different rather than shared values. For instance, faculty may value industry and self-discipline. In contrast, students may value the social aspects of life on campus and find faculty values constraining to their pursuit of pleasure. In addition, as student bodies become more diverse, the students themselves arrive with differing mores, values, and modes of communication (Baldwin, 2002). Faculty and students may also have differing ideas relating to the common good. Faculty may view the purpose of education through a liberal arts lens while students may view their college experience as a means to the end of a well-paying job.

Richardson (2000) states that the root of incivility is failed communications of shared values and mismatched expectations of the common good. He concludes that teachers and students regularly fail to meet each other's expectations and thus--accidentally or purposefully--do things that may be considered uncivil. Boice (1996) reports that incivility occurred in a majority of the classrooms he observed. Schneider (1998, p. A12) states that "close encounters of the uncivil kind are leaving many professors stunned, even shaken."

As part of the academic community, the accounting classroom is not immune to the problem of incivility. The accounting classroom, however, potentially represents a tighter community than the university at large. Accounting students are preparing for the same professional careers that many of the faculty held prior to their entry into academe. Given the positive relation between community and civility, it follows that the level of accounting classroom incivility should be less than the overall levels of classroom incivility demonstrated on campus.

Even though incivility is expected to be lower in the accounting classroom, the issue still needs to be addressed. If accounting faculty deny the presence of classroom incivility, they lose the opportunity to teach acceptable behavior and risk increased unpleasantness (Richardson, 1999). Like all faculty, accounting faculty are responsible for providing an environment that promotes learning. Ethical Principles for College and University Teaching (Murray et al., 1996. p. 2.) states that "the overriding responsibility of the teacher is to contribute to the intellectual development of the student" and to "avoid actions...that detract from student development." Feldman (2001) states that failure to address incivility degrades the learning environment in our classes and in schools as a whole. Anderson (1999) opines that "instructors are responsible for identifying the appropriate rules, norms, and protocols that guarantee or at least maximize the chance that all students can become equal participants in the learning process."

Beyond providing the best learning environment possible, accounting faculty are also responsible for preparing students for successful professional careers. Most university missions aspire not only to student learning but also to student success (Anderson, 1999). Richardson (2000) states that college teachers should model the adult role and make adult behavior expectations explicit. The behavior expectations for public accountants are to "act in a way that will serve the public interest, honor the public trust, and demonstrate commitment to professionalism" (AICPA, 2004, Section 53, Article II). Professionalism requires courtesy, mutual respect, self-restraint, and fairness (Zeff, 2003). Mintz (1995) lists trustworthiness, benevolence, and altruism as enabling virtues for fulfilling the accountants' duty to honor the public trust. These character traits necessary for professionalism all relate to how we interact with others and can be included under the umbrella virtue of civility. As executors of the university missions, accounting faculty should not only model professionalism but should also provide a classroom environment in which students learn to embrace the commitment to professionalism required in their accounting careers. 
The purpose of this research is to investigate accounting faculty perceptions of the definition of incivility and the occurrence of specific student behaviors that are generally viewed as incivilities. In this baseline study, we first compare the perceptions of accounting faculty to the perceptions of cross-disciplinary faculty to determine differences between accounting faculty and their faculty colleagues across campus regarding their definition of inappropriate student behavior and their observation of classroom incivility. We then compare accounting faculty perceptions of the importance and occurrence of various student behaviors with the perceptions of administrators to examine the level of awareness of administrators to incivility in the classroom.

The results should be of interest to faculty in all disciplines who desire to provide the best possible learning environment for their students. The findings are important to accounting faculty who are preparing students for a career in which they are expected to demonstrate a commitment to professionalism. Finally, the findings of this research may be useful to administrators in developing policies designed to prevent and react to classroom incivilities.

\section{LITERATURE REVIEW AND HYPOTHESES DEVELOPMENT}

Most of the literature relating to classroom incivility is definitive and practical in nature. Feldman (2001) defines classroom incivility as any action that interferes with a harmonious and cooperative learning atmosphere in the classroom. Incidents of classroom incivility reported in the press range from descriptions of students who gripe, chat, eat, sleep, and/or swear in class (Clayton, 2000) to investigations of students who physically attack their professors (Ristine, 1996). Appleby (1990) categorizes uncivil behavior as immature behaviors, inattentive behaviors, and miscellaneous irritating behaviors. Gonzalez and Lopes (2001) identify classroom incivilities as disengaged, disinterested, disrespectful, disruptive, defiant, and disturbed behaviors (Gonzalez and Lopez, 2001).

DeLucia \& Iasenza (1995) classify classroom incivility into three categories of behaviors viewed as disruptive or disrespectful by faculty. First, aggressive student behaviors range from insensitivity to the feelings of others to physical altercations. Second, irresponsible student behaviors relate to actions indicating that the student has failed to take responsibility for their own learning. These behaviors are considered incivilities because they indicate a lack of respect toward the instructor who outlined the course requirements and a lack of respect for the class since the student will not be able to contribute to class discussion. On the other hand, irresponsible student behaviors may be exhibited by students who are very prepared but prevent others from participating in the learning process by dominating class discussion. Finally, inappropriate student behaviors are described as behaviors felt to erode a healthy classroom environment. These are behaviors that might be considered rude or annoying both inside and outside of the classroom. Anderson (1999) states that although these behaviors are not extreme and often do not violate student codes, the cumulative effect of inappropriate behaviors takes a toll on students as they expend energy to cope with them. Specific behaviors which could be included in each category are reported in Table 3 in the Results section.

Although all would agree that physical attacks or violent outbreaks represent incivility, faculty may not agree whether behaviors such as cell phone disruptions or arriving late for class really interfere with the learning process and thus should be considered classroom incivility. Accounting faculty are preparing students for professional careers. Consequently, accounting faculty may view disruptive student behaviors as more problematic than general education faculty, or even business college administrators, leading to the following hypotheses:

H1: Accounting faculty are more likely to define disruptive student behaviors as incivility than crossdisciplinary faculty.

H2: Accounting faculty are more likely to define disruptive student behaviors as incivility than business college administrators.

Prior literature discusses factors that contribute to the level of classroom incivility. First, Richardson (2000) asserts that failure to communicate clear course expectations leads to the development of classroom incivility. Davis (2002) states that students arrive on campus expecting academic success based on their high school experiences of minimal studying and reading, coupled with a part-time job that takes up the major portion of the week's hours. The 2004 Higher Education Research Institute at UCLA survey reports that approximately half of 
college freshmen earned an A average in high school (Farrell, 2005). The 2005 survey reports that approximately a third of first-generation students and a fourth of their peers expect to work full time while attending college (Hoover, 2006). The 2008 survey reported that approximately half of college freshman plan on getting a job to meet their college expenses (Redden, 2009). Davis (2002) reports that students found college courses more demanding and stressful than they expected. In addition to course expectation, Schneider (1998) recommends that faculty also communicate their definition of acceptable and unacceptable behavior on 'day one' since both faculty and students come to class with varying ideas as to what constitutes incivility. Similarly, Connelly (2009) proposes the use of a published Code of Academic Civility in first-year college classes to stimulate an initial discussion of the importance of civility and specific values for guiding class interactions.

In addition to failure to communicate expectations, Boice (1996) believes that teachers initiate classroom incivility in additional ways. He states that "not until teachers' negativities confirm student's skepticism (and exacerbate the playful or exploratory classroom incivility of settling in and of testing how teachers will respond) do incivilities become salient and problematic." Sorcinelli (1994) concludes that the level of incivility in the classroom could be reduced by faculty reflection on how personal deportment in the classroom contributes to a difficult situation. In addition, the level of classroom incivility may be driven by personal characteristics beyond the control of the professor (Indiana, 2000; Kuhlenschmidt and Layne, 1999; Schneider, 1998). Feldman (2001) states that faculty who are younger or less experienced are not predestined for, but are certainly more susceptible to challenge in the classroom.

Student and classroom characteristics may also drive the level of classroom incivility. A survey conducted by Indiana University (2000) reported that faculty believe that male students more than female students and undergraduate students more than graduate students are likely to engage in classroom incivility. Kuhlenschmidt and Layne (1999) suggest that physical causes such as psychiatric disorders, medication, illness, or fatigue may contribute to classroom incivility. They also recognize that emotional factors such as a recent loss, low levels of maturity, or redirected aggression may factor into classroom incivility. Finally, Kuhlenschmidt and Layne (1999) note that reasons for disruptive behavior may be environmental.

Classroom incivility is more likely to occur in large than small classes (Indiana, 2000; Morrissette, 2001). Boice (1996) defines large classes as lecture-hall classes with an enrollment over 100. Carbone (1999) states that since students feel anonymous in these settings, they sometimes engage in behaviors they would not exhibit in smaller classes. Classroom incivility is also more likely to occur in general education classes than in classes required for a student's major. Many students come to college because of their need to obtain a degree to secure employment (Morrissette, 2001). Thus, they view non-major courses as irrelevant to their career interests (DeLucia \& Iasenza, 1995; Davis, 2002).

Prior studies have examined the occurrence of classroom incivility in the general education classroom from both student and faculty perspectives. Boice (1996) observed both students and teachers and found that classroom incivility was "more common than uncommon," occurring in significant ways in over two-thirds of the courses observed. Boice also noted that students perceived only half as many incidents of classroom incivility as did their teachers. Lynch and McNaughton-Cassill (2004) report that students found the most frequently occurring types of student incivility to be preparing to leave class early; eating, drinking, and chewing gum in class; and use of cell phones and beepers in class. Similarly, students at Wright State University (2001) reported that the most problematic behaviors included talking in class/disrupting others, preparing to leave class early, and late arrivals/early departures. A survey of almost 1500 faculty at Indiana University (2000) investigated the frequency of experiences with classroom incivility. Faculty reported higher levels of frequency for inappropriate and irresponsible behaviors and very low levels of frequency for aggressive behaviors. For 23 out of the 30 behaviors included in the survey, over $80 \%$ of the faculty reported that they had observed the incivility in their classrooms.

In summary, the extant literature discusses factors that contribute to the level of classroom incivility and reports the results of faculty/student surveys regarding the occurrence of classroom incivility. These surveys (Lynch and McNaughton-Cassill, 2004; Indiana University, 2000; Wright State University, 2001), however, were localized and thus the results may not be generalizable. Boice's (1996) observations were made in sixteen large lecture classes at a large east coast university. Although his findings were generally confirmed in large classrooms at a few other locales, his findings may not be generalizable to smaller classrooms. 
No studies have investigated incivility in the accounting classroom. Although accounting students face the same demands on their time and attention as their peers across campus, we expect the level of incivility to be lower in the accounting classroom. First, incivility should be less in a classroom setting with a strong sense of community. This sense of community is created in the accounting classroom through shared career goals among the students and with their professor. In addition, we expect lower levels of incivility in the accounting classroom because the contents of the course are more directly related to success in the student's chosen career. Finally, career success also depends on the students' willingness to embrace professional standards of conduct. Since acting professionally and acting with civility both demand placing the interest of others above self, we expect students preparing for professional careers in accounting to exhibit less incivility, leading to the following hypothesis:

H3: The level of classroom incivility perceived by accounting faculty is lower than the level of classroom incivility perceived by cross-disciplinary faculty.

Problems of incivility in the classroom are generally not discussed by faculty with either colleagues or superiors. Downs (1992) suggests that faculty do not discuss discipline problems with their colleagues because they do not want to admit that they cannot handle one of their own classes. Amada (1992) states that faculty generally do not report classroom incivility to their superiors until the situation has reached "serious, if not dire, proportions." Amada suggests several reasons for faculty reluctance to report classroom incivility. First, incidents of incivility often go unreported because instructors are hoping for "spontaneous resolution" of the problem. They are hoping that the students will change their ways on their own. Second, faculty are reluctant to report classroom incivility because they are unsure whether administration will take their side or support the student. Further, faculty may fear that upon investigation, the administration may determine that they themselves caused the problem. Third, faculty members are reluctant to report classroom incivility because of consequences that may result for the disruptive student. Finally, faculty may fear reprisal from the offending student. Because of faculty failure to report incidents of incivility to their superiors, administrators may be unaware of the occurrence of incivility in the accounting classroom leading to the following hypothesis:

H4: The level of classroom incivility perceived by accounting faculty is higher than the level of classroom incivility perceived by business college administrators.

\section{RESEARCH METHOD}

To address the hypotheses described above, we conducted a survey of each accounting department at universities in the United States that were listed in Accounting Faculty Directory (Hasselback, 2002). We obtained permission from the Center of Survey Research at the University of Indiana to use their survey instrument which was designed to assess the level of incivility across all disciplines on their campus (Indiana, 2000). We then adapted and added to the questions included in their survey to update the instrument, modify the layout, and gather the demographic data needed to address our research questions. The resulting survey instrument was pilot tested with selected business faculty and administrators to provide increased assurance of representational faithfulness and understandability.

The participants were asked to complete survey questions in the following format:

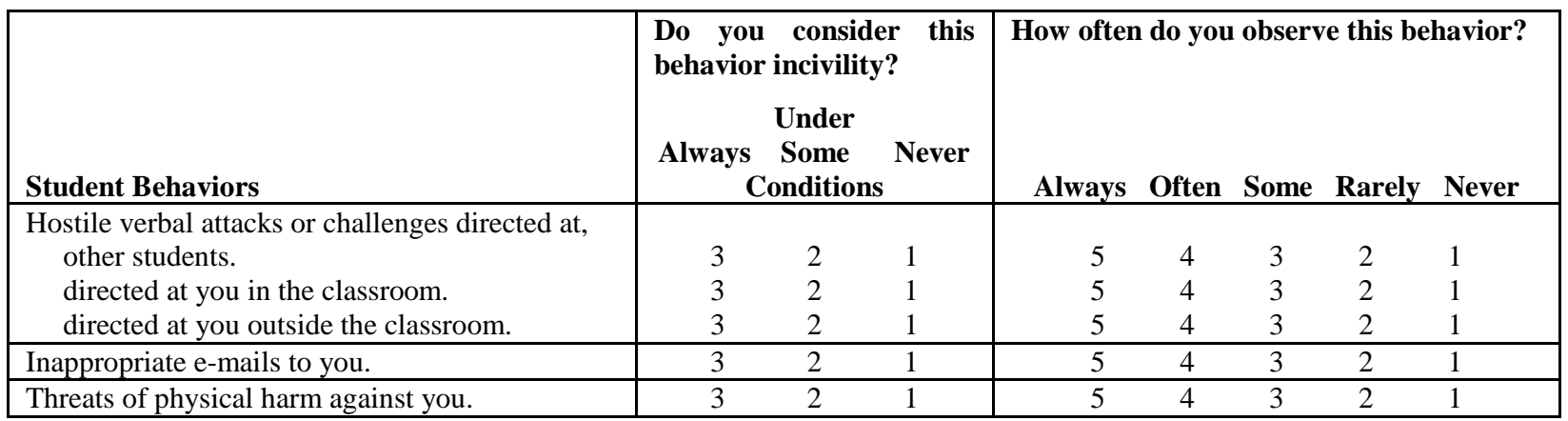


The first and second research hypotheses were tested with responses to the first question- "Do you consider this behavior incivility?" The third and fourth research hypotheses were tested with responses to the second question-"How often do you observe this behavior?" In addition, participants were asked if they had responded to incidents of incivility by reporting a student's behavior to the department, university officials, or the police. Finally, participants were asked to provide demographic information including their age range and their rank.

We mailed surveys to the dean, the department head (director or chair), one full professor, one associate professor, and one assistant professor at each school. Some departments did not have a faculty member at each rank and thus received less than five surveys. Since we used a between-subjects research design for this exploratory study, no specific control was established to assure a matching of faculty and administrators within each institution. Deans and department heads received a cover letter asking them to respond with respect to their roles as administrators of accounting programs with the following verbiage:

Dear Business/Accounting Administrator:

We are conducting a study of classroom incivility as it is currently experienced in accounting classrooms. Classroom incivility is ...

Enclosed is a brief survey that we've shared with one or more of your accounting faculty. Please complete it from your perspective as an administrator. It should take no more than 15 minutes for you to complete. Estimates on your part will be appreciated where exact information is uncertain. Your cooperation in completing the survey will enable us to develop and share an understanding for the scope of this problem in accounting classes.

This sampling procedure resulted in a total of 3,011 surveys in the initial March 2003 mailing. A second mailing was made in April 2003 to non-respondents resulting in an overall response rate of $15.2 \%$ for our analysis. Table 1 summarizes the number of surveys mailed, the number of surveys returned, and the response rates by respondent position and rank. The response rate was $18.3 \%$ for faculty and $10.4 \%$ for administrators.

\begin{tabular}{|c|c|c|c|c|c|}
\hline \multicolumn{6}{|c|}{ Table 1: Surveys Mailed and Respondents } \\
\hline & \multicolumn{2}{|c|}{ Surveys Mailed* } & \multicolumn{2}{|c|}{ Respondents } & \multirow{2}{*}{$\begin{array}{c}\begin{array}{c}\text { Response } \\
\text { Rate }\end{array} \\
\% \\
\end{array}$} \\
\hline & $\mathbf{n}$ & $\%$ & $\mathbf{n}$ & $\%$ & \\
\hline \multicolumn{6}{|l|}{ Faculty } \\
\hline Assistant Professor & 623 & 20.7 & 87 & 19.0 & 13.9 \\
\hline Associate Professor & 654 & 21.7 & 112 & 24.5 & 17.1 \\
\hline Professor & 522 & 17.3 & 120 & 26.2 & 22.9 \\
\hline No rank indicated & & & 11 & 2.4 & \\
\hline Total faculty & 1799 & 59.7 & 330 & 72.2 & 18.3 \\
\hline \multicolumn{6}{|l|}{ Administrators } \\
\hline Chairs & 582 & 19.3 & & & \\
\hline Deans & 630 & 20.9 & & & \\
\hline Total administrators & 1212 & 40.3 & 127 & 27.8 & 10.4 \\
\hline Totals & 3011 & 100.0 & 457 & 100.0 & 15.2 \\
\hline
\end{tabular}


To compare the responses from our respondents to the cross-disciplinary faculty at Indiana University, we downloaded the publically-available survey report at the Indiana University website (Indiana, 2000). The survey report contained frequency and percentage data relating to both the definition and occurrence of incivility in the college classroom.

\section{RESULTS}

The responses to the survey came from accounting faculty and administrators of all ranks and across all the age ranges as reported in Table 2. As would be expected, administrators were older and of higher rank. Respondents over 50 years in age represented $52.4 \%$ of faculty, but were $78 \%$ of administrators. In addition, $36.4 \%$ of faculty respondents were full professors, whereas $59.8 \%$ of administrator respondents were of that rank. Table 2 also shows that only $28 \%$ of the faculty respondents reported incidents of incivility to the department, university officials, or the police.

\begin{tabular}{|c|c|c|c|c|c|c|}
\hline \multicolumn{7}{|c|}{ Table 2: Respondent Demographics } \\
\hline & \multicolumn{2}{|c|}{ Faculty } & \multicolumn{2}{|c|}{ Administrators } & \multicolumn{2}{|c|}{ Total } \\
\hline & $\mathbf{n}$ & $\%$ & n & $\%$ & $\mathbf{n}$ & $\%$ \\
\hline \multicolumn{7}{|l|}{ Age } \\
\hline$<40$ & 41 & 12.4 & 4 & 3.1 & 45 & 9.9 \\
\hline $41-50$ & 116 & 35.2 & 24 & 18.9 & 140 & 30.6 \\
\hline $51-60$ & 126 & 38.2 & 82 & 64.6 & 208 & 45.5 \\
\hline$>60$ & 47 & 14.2 & 17 & 13.4 & 64 & 14.0 \\
\hline Total & 330 & 100.0 & 127 & 100.0 & 457 & 100.0 \\
\hline \multicolumn{7}{|l|}{ Rank } \\
\hline Assistant Professor & 87 & 26.4 & 14 & 11.0 & 101 & 22.1 \\
\hline Associate Professor & 112 & 33.9 & 36 & 28.3 & 148 & 32.4 \\
\hline Professor & 120 & 36.4 & 76 & 59.8 & 196 & 42.9 \\
\hline No rank indicated & 11 & 3.3 & 1 & .8 & 12 & 2.6 \\
\hline Total & 330 & 100.0 & 127 & 100.0 & 457 & 100.0 \\
\hline \multicolumn{7}{|l|}{ Reported Incivility } \\
\hline Assistant Professor & 22 & 23.9 & 7 & 16.3 & 29 & 21.5 \\
\hline Associate Professor & 29 & 31.5 & 10 & 23.3 & 39 & 28.9 \\
\hline Professor & 41 & 44.6 & 26 & 60.5 & 67 & 49.6 \\
\hline Total reporting incivility & 92 & 100.0 & 43 & 100.0 & 135 & 100.0 \\
\hline Percent reporting incivility & & 27.9 & & 33.9 & & 29.5 \\
\hline
\end{tabular}

To determine the potential for non-response bias, we split the responses into early and late categories and compared responses across these two groups. In no instance did we find any significant differences in these groups' responses relating to the definition of incivility or the occurrence of incivility.

\section{Definition of Incivility—Accounting Faculty Compared to Cross-Disciplinary Faculty}

Table 3 presents the specific behaviors that were included in each category of classroom incivility. The percentages of participants who always consider specific student behaviors as incivility are also presented in Table 3 , along with the percentages of Indiana University faculty. Not surprisingly, the results indicate a decreasing sense of importance for both groups of faculty from the aggressive student behaviors shown at the top of the table to the inappropriate student behaviors shown at the bottom of the table. 


\begin{tabular}{|c|c|c|c|}
\hline \multicolumn{4}{|c|}{$\begin{array}{l}\text { Table 3: Behaviors Perceived to be Incivility in the Accounting Classroom } \\
\text { (Percent indicating Always) }\end{array}$} \\
\hline & $\begin{array}{c}\text { University of } \\
\text { Indiana } \\
(n=1449)\end{array}$ & $\begin{array}{c}\text { Accounting } \\
\text { Faculty } \\
(\mathbf{n}=334) \\
\end{array}$ & $\begin{array}{c}\text { Admini- } \\
\text { strators } \\
(\mathrm{n}=\mathbf{1 2 8}) \\
\end{array}$ \\
\hline \multicolumn{4}{|l|}{ Aggressive Student Behaviors } \\
\hline $\begin{array}{l}\text { Harassing comments concerning race, ethnicity, or gender, made in the } \\
\text { classroom? }\end{array}$ & & 94.0 & 97.6 \\
\hline $\begin{array}{l}\text { Harassing comments concerning race, ethnicity, or gender, directed at you } \\
\text { in the classroom? }\end{array}$ & 95.7 & 92.7 & 95.2 \\
\hline $\begin{array}{l}\text { Harassing comments concerning race, ethnicity, or gender, directed at you } \\
\text { outside the classroom? }\end{array}$ & & 89.1 & 89.5 \\
\hline $\begin{array}{l}\text { Other harassing comments including vulgarity or profanity made in the } \\
\text { classroom? }\end{array}$ & & 92.7 & 89.7 \\
\hline $\begin{array}{l}\text { Other harassing comments including vulgarity or profanity directed at you } \\
\text { in the classroom? }\end{array}$ & 91.4 & 92.7 & 95.2 \\
\hline $\begin{array}{l}\text { Other harassing comments including vulgarity or profanity directed at you } \\
\text { outside the classroom? }\end{array}$ & 89.3 & 87.0 & 92.7 \\
\hline Hostile verbal attacks or challenges directed at other students? & & 89.5 & 92.1 \\
\hline Hostile verbal attacks or challenges directed at you in the classroom? & 89.6 & 89.5 & 87.3 \\
\hline Hostile verbal attacks or challenges directed at you outside the classroom? & & 85.9 & 85.7 \\
\hline Inappropriate e-mails to you? & 73.9 & 76.6 & 67.5 \\
\hline Threats of physical harm against you? & 98.1 & 95.8 & 95.2 \\
\hline \multicolumn{4}{|l|}{ Irresponsible Student Behaviors } \\
\hline Sleeping in class & 49.2 & 61.9 & 56.8 \\
\hline Not paying attention in class & 65.0 & 34.4 & 25.6 \\
\hline Not taking notes during class & 2.7 & 9.1 & 5.6 \\
\hline Conversation distracting other students & 73.6 & 81.6 & 76.2 \\
\hline Conversation distracting you & 73.6 & 75.0 & 75.2 \\
\hline Reluctance to answer direct questions & 6.2 & 10.4 & 11.9 \\
\hline Using a computer in class for purposes not related to the class & 68.7 & 64.6 & 58.5 \\
\hline Cell phone or pager disruptions during class & 71.2 & 77.6 & 80.2 \\
\hline Arriving late for class & 22.2 & 37.2 & 34.1 \\
\hline Coming and going during class & & 35.6 & 40.5 \\
\hline Leaving early from class & 22.8 & 22.0 & 21.4 \\
\hline Cutting class & 16.4 & 19.7 & 16.7 \\
\hline Being unprepared for class & 17.0 & 22.5 & 20.0 \\
\hline Creating tension by dominating discussion & 10.7 & 29.4 & 16.1 \\
\hline Cheating on exams or quizzes & 85.5 & 89.8 & 90.3 \\
\hline Demanding make-up exams, extensions, grade changes, or special favors & 32.3 & 50.3 & 47.2 \\
\hline Taunting or belittling other students? & 93.6 & 89.7 & 92.8 \\
\hline Challenging your knowledge or credibility in class? & 22.0 & 39.2 & 33.9 \\
\hline \multicolumn{4}{|l|}{ Inappropriate Student Behaviors } \\
\hline Chewing gum in class & 5.0 & 5.4 & 11.9 \\
\hline Eating in class & 18.0 & 17.7 & 28.0 \\
\hline Acting bored or apathetic & 24.4 & 35.2 & 26.2 \\
\hline Disapproving groans & 41.0 & 49.8 & 44.4 \\
\hline Sarcastic remarks or gestures & 61.2 & 61.2 & 63.7 \\
\hline
\end{tabular}

The percentages reported in Table 3 suggest that accounting faculty are more likely to define disruptive student behavior as incivility indicating a lower level of tolerance for uncivil behaviors than the cross-disciplinary Indiana University faculty. To investigate the differences in how accounting faculty define incivility and how crossdisciplinary faculty define incivility, we compared the mean faculty response between groups by category. Panel A of Table 4 reports that in each instance, the difference is significant. Accounting faculty were more likely to consider irresponsible and inappropriate student behaviors as incivility than the Indiana faculty. Although the mean 
responses for both accounting faculty and Indiana faculty indicated that they "always" consider aggressive student behaviors as incivility, the mean response for Indiana faculty was higher than the accounting faculty response.

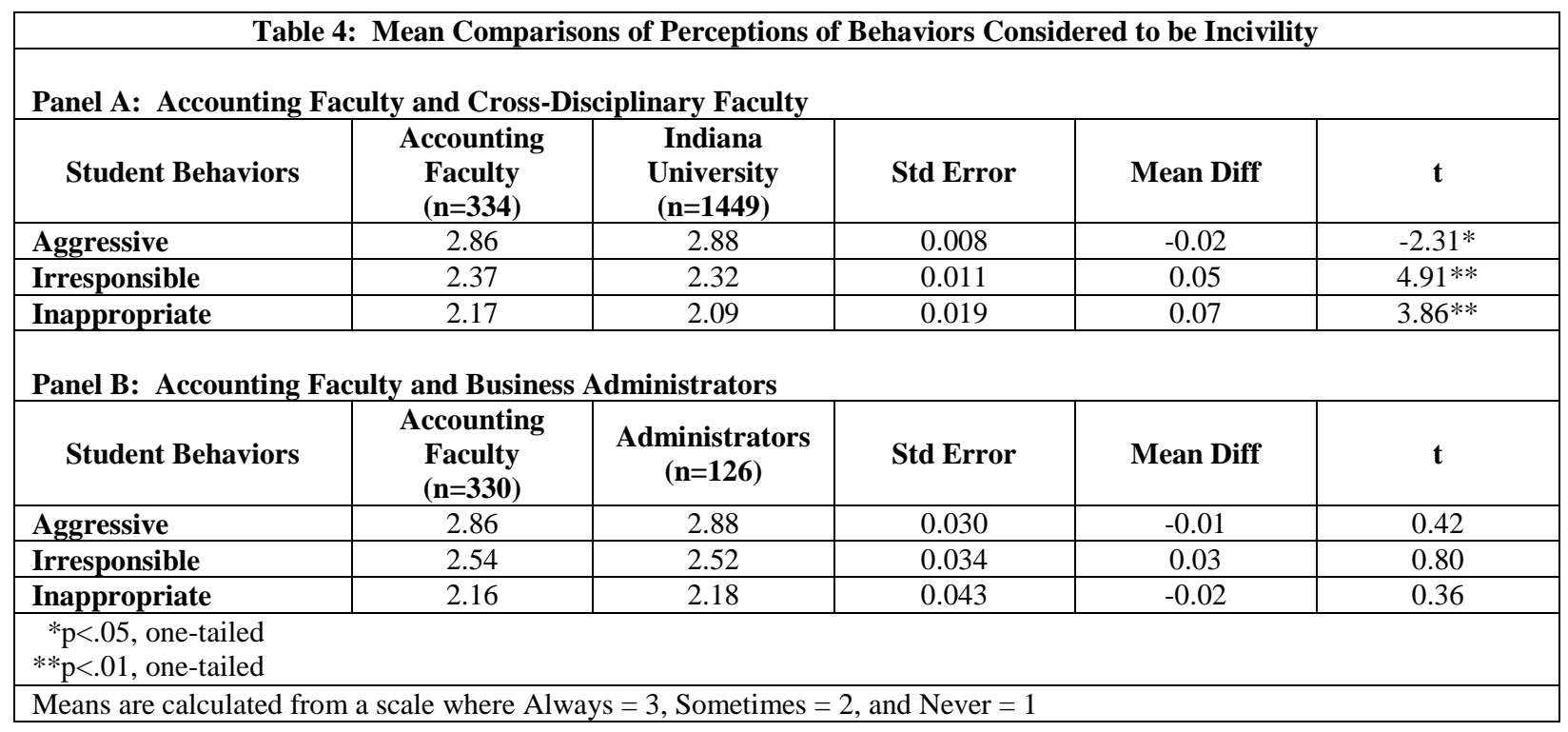

Our evidence provides mixed support for $\mathrm{H} 1$ - that accounting faculty are more likely to define disruptive student behaviors as incivility than cross-disciplinary faculty. Our results support H1 for the irresponsible and inappropriate behavior categories, but not for the aggressive student behavior category.

\section{Definition of Incivility—Accounting Faculty Compared to Business College Administrators}

The results comparing definitions of incivility between accounting faculty and business college administrators are also presented in Table 3. No systematic differences are discernable from the proportions. A number of the individual behaviors appear to be more problematic to faculty while others are more problematic to administrators.

Panel B of Table 4 presents the mean responses of accounting faculty compared to the business college administrators by behavior category. The differences between the means are not statistically significant in any of the behavior categories. We find no support for $\mathrm{H} 2$ - that accounting faculty are more likely to define disruptive student behaviors as incivility than business college administrators.

\section{Occurrence of Incivility-Accounting Faculty Compared to Cross-disciplinary Faculty}

Table 5 presents the percentages of both accounting and cross-disciplinary Indiana University faculty who reported that they "often or always" observe the indicated student incivilities. The results, as expected, indicate an increasing level of occurrence from the aggressive student behaviors reported at the top of the table to the inappropriate student behaviors shown at the bottom of the table. We expected that accounting professors would report lower levels of classroom incivility than the levels reported by cross-disciplinary faculty at Indiana University based on prior research indicating that incivility is lower in classes related to a student's major than in general education classes. The responses of accounting faculty, however, are not lower than the levels reported by the crossdisciplinary faculty. To investigate the differences in the level of incivility observed by accounting faculty and cross-disciplinary faculty, we compared the mean faculty response between groups by behavior category. Panel A of Table 6 reports that in each instance, the difference is significant. Further, in each category, the level of incivility observed by accounting faculty is higher. 


\begin{tabular}{|c|c|c|c|}
\hline \multicolumn{4}{|c|}{$\begin{array}{c}\text { Table 5: Perceived Level of Incivility in the Accounting Classroom } \\
\text { (Percent indicating Often or Always) }\end{array}$} \\
\hline & $\begin{array}{l}\text { University of } \\
\text { Indiana } \\
(n=1449)\end{array}$ & $\begin{array}{c}\text { Accounting } \\
\text { Faculty } \\
(\mathbf{n}=334)\end{array}$ & $\begin{array}{c}\text { Admini- } \\
\text { strators } \\
(n=128)\end{array}$ \\
\hline \multicolumn{4}{|l|}{ Aggressive Student Behaviors } \\
\hline $\begin{array}{l}\text { Harassing comments concerning race, ethnicity, or gender, made in } \\
\text { the classroom? }\end{array}$ & & 2.4 & 1.6 \\
\hline $\begin{array}{l}\text { Harassing comments concerning race, ethnicity, or gender, directed } \\
\text { at you in the classroom? }\end{array}$ & 0.0 & 1.2 & 0.8 \\
\hline $\begin{array}{l}\text { Harassing comments concerning race, ethnicity, or gender, directed } \\
\text { at you outside the classroom? }\end{array}$ & & 3.3 & 0.8 \\
\hline $\begin{array}{l}\text { Other harassing comments including vulgarity or profanity made in } \\
\text { the classroom? }\end{array}$ & & 2.4 & 1.6 \\
\hline $\begin{array}{l}\text { Other harassing comments including vulgarity or profanity directed } \\
\text { at you in the classroom? }\end{array}$ & 0.0 & 1.5 & 0.0 \\
\hline $\begin{array}{l}\text { Other harassing comments including vulgarity or profanity directed } \\
\text { at you outside the classroom? }\end{array}$ & 0.4 & 2.4 & 0.8 \\
\hline Hostile verbal attacks or challenges directed at other students? & & 3.6 & 3.2 \\
\hline $\begin{array}{l}\text { Hostile verbal attacks or challenges directed at you in the } \\
\text { classroom? }\end{array}$ & 0.1 & 2.4 & 1.6 \\
\hline $\begin{array}{l}\text { Hostile verbal attacks or challenges directed at you outside the } \\
\text { classroom? }\end{array}$ & & 4.2 & 3.2 \\
\hline Inappropriate e-mails to you? & 1.1 & 6.6 & 7.3 \\
\hline Threats of physical harm against you? & 0.1 & 0.6 & 0.0 \\
\hline \multicolumn{4}{|l|}{ Irresponsible Student Behaviors } \\
\hline Sleeping in class & 5.7 & 6.7 & 4.0 \\
\hline Not paying attention in class & 6.9 & 27.4 & 27.4 \\
\hline Not taking notes during class & 18.0 & 31.8 & 32.5 \\
\hline Conversation distracting other students & 9.7 & 14.3 & 13.7 \\
\hline Conversation distracting you & 7.0 & 9.7 & 8.2 \\
\hline Reluctance to answer direct questions & 6.1 & 17.5 & 12.1 \\
\hline Using a computer in class for purposes not related to the class & 3.1 & 3.4 & 3.3 \\
\hline Cell phone or pager disruptions during class & 0.2 & 6.0 & 3.2 \\
\hline Arriving late for class & 30.8 & 37.9 & 28.5 \\
\hline Coming and going during class & & 15.7 & 10.5 \\
\hline Leaving early from class & 10.0 & 7.9 & 10.5 \\
\hline Cutting class & 28.7 & 33.0 & 29.6 \\
\hline Being unprepared for class & 27.9 & 47.4 & 38.8 \\
\hline Creating tension by dominating discussion & 2.0 & 2.4 & 1.6 \\
\hline Cheating on exams or quizzes & 0.7 & 1.5 & 4.9 \\
\hline $\begin{array}{l}\text { Demanding make-up exams, extensions, grade changes, or special } \\
\text { favors }\end{array}$ & 9.5 & 9.4 & 11.4 \\
\hline Taunting or belittling other students? & 0.1 & 0.3 & 0.0 \\
\hline Challenging your knowledge or credibility in class? & 0.8 & 1.2 & 0.0 \\
\hline \multicolumn{4}{|l|}{ Inappropriate Student Behaviors } \\
\hline Chewing gum in class & 15.1 & 17.4 & 22.1 \\
\hline Eating in class & 10.8 & 23.4 & 13.8 \\
\hline Acting bored or apathetic & 14.3 & 35.4 & 29.0 \\
\hline Disapproving groans & 2.8 & 6.3 & 7.2 \\
\hline Sarcastic remarks or gestures & 2.1 & 3.0 & 5.6 \\
\hline
\end{tabular}

Our evidence suggests clear refutation for $\mathrm{H} 3$ - that the level of classroom incivility perceived by accounting faculty is lower than the level of classroom incivility perceived by cross-disciplinary faculty. Our survey results are exactly the opposite. 


\begin{tabular}{|c|c|c|c|c|c|}
\hline \multicolumn{6}{|c|}{ Table 6: Mean Comparisons of Perceived Occurrence of Classroom Incivility } \\
\hline \multicolumn{6}{|c|}{ Panel A: Accounting Faculty and Cross-disciplinary Faculty } \\
\hline Student Behaviors & $\begin{array}{c}\text { Accounting } \\
\text { Faculty } \\
(\mathbf{n}=\mathbf{3 3 0}) \\
\end{array}$ & $\begin{array}{c}\text { Indiana } \\
\text { University } \\
(\mathrm{n}=1373) \\
\end{array}$ & Std Error & Mean Diff & $\mathbf{t}$ \\
\hline Aggressive & 1.28 & 1.16 & 0.009 & 0.11 & $11.95 * *$ \\
\hline Irresponsible & 2.51 & 2.22 & 0.014 & 0.30 & $21.50 * *$ \\
\hline Inappropriate & 2.60 & 2.32 & 0.024 & 0.28 & $11.50 * *$ \\
\hline \multicolumn{6}{|c|}{ Panel B: Accounting Faculty and Business Administrators } \\
\hline Student Behaviors & $\begin{array}{c}\text { Accounting } \\
\text { Faculty } \\
(\mathbf{n}=\mathbf{3 3 0}) \\
\end{array}$ & $\begin{array}{c}\text { Administrators } \\
(\mathbf{n}=\mathbf{1 2 4})\end{array}$ & Std Error & Mean Diff & $\mathbf{t}$ \\
\hline Aggressive & 1.27 & 1.29 & 0.035 & -0.02 & -0.47 \\
\hline Irresponsible & 2.54 & 2.52 & 0.046 & 0.02 & 0.33 \\
\hline Inappropriate & 2.62 & 2.62 & 0.057 & 0.00 & 0.05 \\
\hline \multicolumn{6}{|l|}{$* * \mathrm{p}<.01$, one-tailed } \\
\hline
\end{tabular}

\section{Occurrence of Incivility—Accounting Faculty Compared to Business College Administrators}

The results comparing perceived occurrence of incivility by accounting faculty and business college administrators are presented in Table 5. A number of the individual behaviors appear to be more problematic to faculty while other behaviors are more problematic to administrators. Panel B of Table 6 compares the perceived occurrence of incivility reported by accounting faculty and business college administrators across behavior categories. The mean difference between groups is not statistically significant for any of the behavior categories. We find no evidence of support for H4 - that the level of incivility perceived by accounting faculty is higher than the level of incivility perceived by business college administrators.

\section{DISCUSSION AND CONCLUSION}

The purpose of this paper was to investigate the definition of incivility by accounting faculty and the occurrence of incivility in the accounting classroom. We compared what behaviors accounting faculty considered to be incivility to the behaviors considered to be incivility by both cross-disciplinary faculty and business college administrators. We also compared the level of incivility observed in the classroom by accounting faculty to the level of classroom incivility observed by cross-disciplinary faculty and the level of classroom incivility perceived by business college administrators. Addressing incivility in the accounting classroom is important for preparing students to respond to situations they will encounter in their careers. CPAs are bound by the AICPA (2004) Code of Professional Conduct to demonstrate professionalism. The defining characteristic of professionalism is a willingness to sacrifice self-interest for the public interest. The defining characteristic of civility is similarsacrifice of self for the sake of the common good. We cannot expect individuals to someday make sacrificial professional judgments that are in the public interest, if these same individuals as students were not willing to simply turn off their cell phones, get to class on time, or refrain from chatting with their neighbors for the sake of an improved learning environment for their fellow classmates. Further, we cannot expect individuals to someday professionally complete their engagements with due care if they are not willing as students to complete homework assignments, take notes during class, or even come to class. Fostering civility in the classroom builds professionalism and thus prepares students for successful entry into professional accounting careers. Beyond their own self-interest, however, fostering civility in the classroom prepares students to consider the impact their positive behavior or their restraint from negative behaviors has on the greater good.

Prior literature has presented the results of localized student/faculty surveys relating to definitions of and levels of incivility in the general education classroom. In our nation-wide survey of accounting faculty and business college administrators, we expected that accounting faculty who are preparing students for careers as professionals 
would be less tolerant of incivility. While civility calls for sacrifice of self for the common good, professionalism calls for sacrifice of self-interest for the public interest (Abbott, 1988; Parsons, 1939). When compared to the responses of the cross-disciplinary faculty at Indiana University (2000), we found that accounting faculty are more likely to define irresponsible and inappropriate student behaviors as incivility as expected. For these more common student incivilities, we found that accounting faculty are less tolerant of disruptive student behaviors. Although the mean responses of accounting and cross-disciplinary faculty indicated that both groups "always" defined aggressive student behaviors as incivility, the responses from the cross-disciplinary faculty were higher.

We also expected occurrence of incivility to be lower in the accounting classroom than in classrooms across the campus. We based this expectation on the positive relationship between community and civility. Since the accounting classroom has a stronger sense of community resulting from students and faculty sharing career goals, we expected higher levels of civility and thus lower levels of incivility. The results of our research, however, actually indicated higher levels of incivility in the accounting classroom than the level of incivility reported across all disciplines at Indiana University (2000).

Interpretation of these results is difficult. The higher levels of incivility in the accounting classroom may be driven by the higher level of incivility found in society at the time of our survey. Although our survey was mailed just a few years after the Indiana University survey, increased societal incivility could have trickled into academe and the accounting classroom. In addition, just a few years could have affected the level of awareness of the problems of incivility on campus and thus made the accounting faculty more aware and more willing to report higher levels of incivility in the classroom. The observations of higher levels of incivility reported by accounting faculty may also be related to a greater intolerance for these behaviors by accounting faculty. Cross-disciplinary faculty who do not consider a behavior incivility may not even notice when the behavior is occurring.

We find higher levels of incivility in the accounting classroom troubling. Civility encompasses the virtues of trustworthiness, reliability, benevolence, and altruism that are crucial to a profession besought with accounting scandals. Civility thus provides the backbone that Zeff (2003) states is necessary to hold to professional values (promoting the public interest) rather than the business values of growth, profitability and global reach (promoting self interest). We expected accounting students to be committed to the standards of professionalism embodied in the AICPA Code of Professional Conduct. Instead, we found that accounting students, like the rest of the campus, did not even meet the standards of basic civil behavior.

Prior literature reported that faculty members are reluctant to discuss student incivility with either their colleagues or their superiors (Sorcinelli, 1994). Consistent with the literature, a minority of our respondents indicated that they had reported incidents of incivility to their department, university officials, or the police. The results of our research, however, did not show lack of administrator awareness but showed instead that the perceptions of administrators relating to both definition of incivility and levels of incivility are surprisingly similar to perceptions of faculty. Although some administrators may be unaware of the occurrence of classroom incivility, our results may have been mitigated by other administrators who are dealing with multiple reports of classroom incivility. These administrators may actually perceive that incivility is higher than the level perceived by individual faculty members who are relating to a limited number of students in their own classrooms.

Our exploratory research was based on both horizontal and vertical comparisons. We compared accounting faculty perceptions horizontally to their colleagues across campus. We also compared accounting faculty perceptions vertically to their administrative supervisors. Future research could compare the perceptions of accounting faculty relating to classroom incivility to the perceptions of accounting students. Identification of the behaviors that students consider disruptive would help accounting faculty focus their efforts for mitigating incivility.

Our research is limited by omission of controls for other factors that could be influencing the results. Factors such as build, ethnicity, age, and gender have been reported to impact levels of incivility. In addition, factors relating to courses taught and the students enrolled may effect levels of incivility. If courses are large and part of a required core, incivility is likely to be higher. Further, undergraduate students and male students are more likely to engage in uncivil behavior than their counterparts. Finally, factors relating to the institutions may also make a difference. Private schools may have a stronger sense of community and thus lower levels of incivility than 
public schools. Size of the institution as well as location of the institution in a rural or metropolitan area may also contribute to student anonymity and thus higher levels of incivility. Future research could consider the impact of these various factors on both the definition of behaviors as incivility, and the level of incivility in the accounting classroom.

Our research was also limited by issues inherent in the use of the survey data collection method. First, survey participants are subject to problems of recall. Some participants may not have stored details relating to classroom incivility in their memories. Foster (2009) states that small events that have less impact are more likely to be forgotten than more significant events. Foster also notes that survey participants are more likely to recall recent events than events in the past. Memories of recent experiences with disruptive behavior may be more available to survey participants who had just experienced incivilities in the month that they completed the survey. Recency and availability biases (see Tversky and Kahneman, 1973) may have led these subjects to perceive a higher level of incivility than participants who had observed the same behavior several months before. Further, survey participants may be biased toward providing what they view is the socially desirable response (Foster, 2009). For example, respondents who view classroom incivility as a negative reflection of their own teaching ability, may have underreported the level of incivility occurring in their classrooms. Finally, survey respondents may be influenced by the order of the survey questions, the choice of terms, and the presentation of response scales.

Our results are also limited to the perceptions of accounting faculty and business college administrators in the United States. Future research could consider the perceptions of accounting faculty in other cultures. Behaviors considered appropriate in an American classroom might be considered intolerable in classrooms in other parts of the world. Similarly, behaviors considered inappropriate in an American classroom might be considered tolerable in other international classrooms.

These results provide preliminary evidence that incivility happens in the accounting classroom just as it happens in cross-disciplinary classrooms across the country. In order to prepare students for the professional challenges they will one day face, accounting faculty can provide a lab in the classroom for learning acceptable behavior. As students consider the importance of preparing adequately for class and respecting their classmates, a foundation can be made for making professional judgments based on due care that consider the public interest. To prevent and deal with incivility, accounting faculty can follow the recommendations provided in the educational literature (e.g. Sorcinelli, 1994; Schneider, 1998; Morrissette, 2001; Kuhlenschmidt and Layne, 1999). To summarize, civility should first be defined. Since incivility typically escalates with unmet expectations (Richardson, 2000), the course syllabus and the first class should be used to let students know not only course requirements but also what behaviors the professor will tolerate (Sorcinelli, 1994; Morrissette, 2001). Faculty should consider including a statement on civility in their course syllabi (e.g. Gormley, 2002). Institutions are also formulating Classroom Civility Statements to define incivility and its consequences (e.g. Northern Arizona University, 1997; Iowa State University, 2002).

Second, accounting faculty should reward civility by letting students know they appreciate their attentive behavior and good performance on assigned work. Even in large classes, Gleason (1986) recommends selecting twenty or so graded exams and then writing personal comments on them. Just as civility should be rewarded, there should be consequences for incivility. Carbone (1999) states that "there is a large silent majority of students who want to spend their time listening rather than being distracted by a handful of rowdy classmates." Sorcinelli (1994) believes that the best time to handle a problem is when it occurs. Immediate action may range from asking the student to meet you after class to sending the student to an administrator's office for assistance (Kuhlenschmidt and Layne, 1999). Kuhlenschmidt and Layne also acknowledge that waiting a day or two until both parties are calm may facilitate the most desirable resolutions.

Although most faculty initially deal with incivilities individually, it may become appropriate to also inform administrative heads. Administrators may have dealt with similar situations in the past and can be a source of support. Further, administrators do not want to be the last to know about situations that could generate complaints from students or parents. Finally, keeping administrators informed may result in implementation of proactive measures, such as developing or sponsoring seminars addressing incivility. Administrators may also spearhead the creation and implementation of a written policy on incivility. Amada (1993) suggests that this policy include (a) 
definitions of disruptive student behaviors grouped into categories, (b) a general statement of what to do for each category, and (c) administrative procedures following an incident of disruptive behavior.

Finally, accounting faculty must model civility. Boice (1996) believes that teachers and students are partners in generating and exacerbating incivility. Students are annoyed by the same behaviors that annoy faculty. Faculty cannot expect students to arrive on time, refrain from using profanity, come to class prepared, and treat fellow students with respect, unless they hold themselves to those same standards. Kearney and Plax (1992) found that the level of student civility was positively related to the instructor's use of positive motivators and signals of warmth, friendliness, and liking. For instance, Sorcinelli (1994) recommends that faculty learn students' names and Mills (1998) suggests that faculty ask students how they would like to be addressed. These simple acts of immediacy reduce anonymity, build rapport, and create an atmosphere of respect. Defining, rewarding, and modeling civility are first steps toward providing a harmonious and cooperative learning environment for tomorrow's accounting professionals.

\section{AUTHOR INFORMATION}

Bruce Elder holds a J.D. from the University of Nebraska College of Law. He was formerly in private practice as an attorney and is currently a professor of business at the University of Nebraska at Kearney where he teaches graduate and undergraduate courses in business law. His ongoing research interests include business ethics, employment law, and professional licensure issues.

Pat Seaton received his MBA from the University of Arkansas and his PhD. from the University of Nebraska in Lincoln. He is currently an accounting professor at the Monfort College of Business at the University of Northern Colorado. He has taught courses in accounting information systems, cost accounting, auditing, ethics, and fraud.

Laurie Swinney received her MBA from the University of Cincinnati and her PhD from the University of Nebraska in Lincoln. She is currently a professor at the University of Nebraska at Kearney. She teaches in the areas of financial and governmental accounting and her ongoing research interests include accounting ethics and professional licensure issues.

\section{REFERENCES}

1. Amada, G. 1993. Coping with the Disruptive College Student: A Practical Model. College Health (Vol. 40) 203-215.

2. American Institute of Certified Public Accountants (AICPA). 2004. Code of Professional Conduct. Retrieved May 26, 2004 from http://www.aicpa.org/about/code/index.htm.

3. Anderson, J. 1999. Faculty responsibility for promoting conflict-free college classrooms. New Directions for Teaching and Learning 77 (Spring) 69-76.

4. Appleby, D. 1990. Faculty and student perceptions of irritating behaviors in the college classroom. Journal of Staff, Program, and Organizational Development (Vol. 8, No. 1, Spring) 41-46.

5. Baldwin, R. 2002. Academic Civility Begins in the Classroom. A publication of The Professional \& Organizational Development Network in Higher Education.

6. Boice, B. 1996. Classroom Incivilities. Research in Higher Education (Vol. 37, No. 4) 53-486.

7. Boyer, E. 1990. Campus Life: In Search of Community. Lawrenceville, NJ: Princeton University Press.

8. Carbone, E. 1999. Students Behaving Badly in Large Classes. New Directions for Teaching and Learning 77 (Spring) 35-43.

9. Carter, S. 1998. Civility. New York: Harper Perennial.

10. Connelly, R. 2009. Introducing a Culture of Civility in First-Year College Classes. The Journal of General Education (Vol. 58, No. 1) 47-64.

11. Davis, R. 2002. Academic Culture and the Classroom: A Practical Application. Working paper, University of Nebraska at Kearney.

12. della Cava, M. 2009. What Happened to Civility? USA Today (September 14).

13. DeLucia, R., and S. Iasenza. 1995. Student Disruption, Disrespect, and Disorder in Class: A Seminar for Faculty. Journal of College Student Development (Vol. 36, No. 4) 385-388. 
14. Downs, J. 1992. Dealing with Hostile and Oppositional Students. College Teaching (Vol. 40) 106-109.

15. Farrell, E. 2005. More Students Plan to Work to Help Pay for College. The Chronicle of Higher Education (Vol. 51, No. 22) A32-A34.

16. Feldman, L. 2001. Classroom Civility is Another of Our Instructor Responsibilities. College Teaching (Vol. 49, No. 4) 137-140.

17. Foster, F. 2009. Survey Research Methods. Thousand Oaks, CA: Sage.

18. Gleason, M. 1986. Teaching Large Classes: Tools and Strategies. Thousand Oaks, CA: Sage.

19. Gormley, J. 2002. Physical Science 452 classroom syllabus. Retrieved June 25, 2004 from http://www.phy.cmich.edu/people/Gormley/Syllabus452-f02.htm.

20. Hasselback, J. 2002. Accounting Faculty Directory. Englewood Cliffs, NJ: Prentice Hall.

21. Hoover, E. 2006. Freshman Survey: More Students Plan to Lend a Hand. The Chronicle of Higher Education (Vol. 52, No. 22) A40-Q1.

22. Indiana University Center for Survey Research. 2000. A Survey on Academic Incivility at Indiana University: Preliminary report. Bloomington, IN.

23. Kearney, P., and T. Plax. 1992. Power in the Classroom. Hillsdale, NJ: Erlbaum.

24. Kuhlenschmidt, S., and L. Layne. 1999. Strategies for Dealing with Difficult Behavior. New Directions for Teaching and Learning (Vol. 77, Spring) 45-57.

25. Lee, T. 1995. The Professionalization of Accountancy-A History of Protecting the Public Interest in a Self-interested Way. Accounting, Auditing, and Accountability Journal (Vol. 8, No. 4) 48-69.

26. Levine, A., and J. Cureton. 1998. What We Know About Today's College Students. About Campus (March-April) 4-9.

27. Libaw, O. 2003. Missed Manners. ABCNews.com (April 3). Retrieved May 30, 2003, from http://more.abcnews.go.com/sections/us/dailynews/rudeness020403.html.

28. Lynch, M. and McNaughton-Cassill, M. 2004. Student Incivility: Students Annoying Others in the Classroom. Presented at the $50^{\text {th }}$ Annual Covention of the Sourthwestern Psychological Asociation. Retrieved October 31, 2005, from https://www.swpsych.org/programs.heitml? ref=938\&year=2004.

29. Mills, N. 1997. The Triumph of Meanness. New York: Houghton Mifflin.

30. Mintz, S. 1995. Virtue Ethics and Accounting Education. Issues in Accounting Education (Vol. 10, No. 2) 247-267.

31. Morrissette, P. 2001. Reducing Incivility in the University/College Classroom. International Electronic Journal for Leadership in Learning (Vol. 5, No. 4)

32. Murray, H., E. Gillesse, M. Lennon, P. Mercer, and M. Robinson. 1996. Ethical Principles for College and University Teaching. AAHE Bulletin (December). Retrieved June 21, 2004 from http://aahebulletin.com/public/archive/Ethical\%20Principles.asp?pf=1.

33. Redden, E. 2009. What are Freshmen Thinking? Inside Higher Ed (January 22). Retrieved January 25, 2010 from http://www.insidehighered.com/layout/set/print/news/2009/01/22/freshmen.

34. Richardson, S. 1999. Editor's Notes to Promoting civility: A teaching challenge. New Directions for Teaching and Learning 77 (Spring).

35. 2000. Missed Expectations: Incivility in the Classroom. NEA Higher Education Advocate Online (March).

36. Ristine, J. 1996. Thesis as a Factor in Killings Doubted. The San Diego Union Tribune (August 31) B1B3.

37. Royce, A. 1998. Civility: An Uncommon Good, Keynote Presentation at the Campus Forum on Academic Incivility (October 12) Indiana University. Retrieved September 6, 2002 from http://campuslife.indiana.edu/Civility/program/Keynote.html.

38. Schneider, A. 1998. Insubordination and Intimidation Signal the End of Decorum in Many Classrooms. The Chronicle of Higher Education (March 27) A12-A14.

39. Sorcinelli, M. 1994. Dealing with Troublesome Behaviors in the Classroom. In Handbook of College Teaching, ed. K. Prichard and R. Sawyer, 365-373. Westport, CN: Greenwood Press.

40. Tversky, A. and D. Kahneman. 1973. Availability: A heuristic for judging frequency and probability. Cognitive Psychology (Vol. 5): 207-232.

41. U.S. News and World Report Survey. 1996. In J. Marks, 1996. The American Uncivil Wars. U.S. News $\&$ World Report (April 22). 
42. Walsh, D., and M. Maffei. 2002. Never in a Class by Themselves: An Examination of Behaviors Affecting the Student-Professor Relationship. A publication of The Professional \& Organizational Development Network in Higher Education.

43. Wright State Center for Teaching and Learning. 2001. Committee on Classroom Behavior Report Retrieved October 6, 2006, from http://www.wright.edu/ctl/faculty/ resources/ annoying_behaviors.pdf.

44. Yates, A., 1999. Fall Address, September 14, 1999.

45. Zeff, S. 2003. How the U.S. Accounting Profession Got Where It Is Today: Part II. Accounting Horizons (Vol. 17, No. 4) 267-286.

\section{$\underline{\text { NOTES }}$}

